\title{
Quality of Service to the Regional Road Transport Service
}

\author{
Suela E. Shpuza \\ $\mathrm{PhD}$ candidate in management \\ s_shpuza79@yahoo.com
}

\begin{abstract}
Performance is measured and done, the quality represents a key element to achieve the performance, especially customer service quality. In response to the pressure of globalization, the market increasingly competitive and volatile market dynamics that, many organizations actively seeking ways to add value to their services and improve their quality of service. Organizations usually tend to make their operations efficient priority. This process begins with the assessment of nevojave customers, their requirements and assessing the performance of domestic human resources in organization and performance depends on the outcome of the estimated earlier. Since this process can proceed in different directions. The causes of these results may be the lack of information and support of high-level management, performance standards unclear, inaccuracies assessors, very large number of forms to be completed and the use of software for the opposite purpose.
\end{abstract}

Keywords: Quality of Service to the Regional Road Transport Service

\section{Introduction}

Based on the study of literature are formulated questions about the impact of quality of customer service performance network-system Departments of Road Transport Services in Albania, where the interviews are collect information about the process, methods, system and process quality management, applicable standards.

\section{Literature Review}

Matrix balanced scorecard (BSC), which was created by the author Kaplan and Norton. this matrix is a management system that enables organizations to clarify the vision and their strategy and translate them into concrete actions. (Kaplan \& Norton, 1992). Also, this model provides feedback on internal business processes and external at the same time about their results. (Kaplan \& Norton, 1993). BSC-lo It suggests that organizations should be judged from four perspectives, develop quality measuring instruments to collect data and analyze them according to each of the prospects. These prospects are consumers, finance, process and innovation \& learning.

\section{Metodoloy}

The methodology has helped us practically easier to make a comparison of variables to test the hypothesis set. Another method used in this paper is descriptive method through which marketing strategies have been described by various authors mentioned in the literature review.

Methods to be used are:

- qualitative method through direct interviews

- quantitative method through structured questionnaire

In the first phase of qualitative methods I use half structured interview as instrument of collection of qualitative data (with representatives of the managements of companies that will be part of that study will not be put aside nor employees). 
In the second phase, quantitative methods will be used questionnaire structured as a technician for collecting data (for the purpose of comparing the empirical data questionnaire will serve therefore to collect data which will then be analyzed with software SPSS and statistical tests will be conducted to confirm or reject the hypotheses mentioned above. ).

The methodology used for collecting data in the field is based on conducting interviews with these subjects: consumer, with executives \& managers Departments of Road Transport Services in Albania. After analyzing secondary data; Well editorial materials research process has started, which was originally identified from the ground state by measuring the variables, it through the interviews which aimed confirmation of hypotheses

During operation is used quantitative methods of data collection, ie questionnaires were used to collect data. This has helped us do that more easily compare the different variables used to test the hypotheses submitted. Another method used in this paper is descriptive method through which marketing strategies have been described by various authors mentioned in the literature review.

Paving the categories specified questionnaires we managed to get the answer always based on a conceptual scheme of study, as well as the study of the econometric model.

Considering the interpretation of hypotheses, their analysis is built by sharing and relevant hypotheses.

\section{Conclusion}

"Quality is fitness for use" (Juran, 1979); "Quality is conformity to requirements" (Crosby, 1979), "It is an agreement provided for uniformity and dependence with low costs by adapting to the market" (Deming, 1982, quoted in 1993), Other scholars as Feigenbaum (1983), essentially defining quality as "a way of managing the organization" Six years later, Oakland gave a more practical sense this term implying the latter "fulfilling consumer demands"

After 90 years, with the creation of the International Standards ISO "is the total quality of the characteristics of an entity that appears on its ability to satisfy the needs expressed or implied", (ISO 8482: 1994: vii)

Japanese standards for the industry, the word "entity" used by ISO substitute the word "goods and services", implying quality, "the production system in order economic goods and services that satisfy the demands of workers".

Feigenbaum researcher extends the meaning of this concept in an organization and planning is starting for the first time to highlight what would later be called Total Quality Management.

Quality management in the organizational context will be the application of certain practices and certain techniques, which ensure that the final product or output of an organization, a product or service that is of a high standard.

At an organizational level, the variables that affect the quality of a product or service include those factors that influence the organization in its entirety internally and externally. In analogy with the private sector, the quality has always played a role in public administration, less stated that in the private sector, but its meaning has evolved in recent years

Beltram public sector author distinguishes three stages in the evolution of quality are:

Quality in the sense of respecting the norms and procedures

Quality in the sense of effectiveness

Quality in the sense of consumer satisfaction 
In many countries, public administration a significant place of widely sound economic sector which includes employment and production of goods and services. Consequently, we can not remain indifferent to Quality Management in Public Administration.

French public sector has often experience low-quality services, which has led to the generation of low expectations for citizens. The result has been a disappointment and effort without charge but not much real action.

After 90 years the situation took a different direction. Albania appears to be making efforts to modernize the public sector and improving the quality of public services, in an effort to integrate into the EU, which also puts pressure on the expansion of administrative capacity. Albania has taken its first steps towards the implementation of Quality Management.

Quality management has gone through a significant evolution from simply inspection of products to the creation of a completely different vision for the organizations strategy.

Public transport in Albania found major problems faced many as the original of all the problems is the presence of more cars / motor vehicles in traffic compared with public transport; which implies that citizens prefer private transport compared with the public. This situation puts Albania in the ranking of countries with traffic charge.

The main centers are Tirana traffic charge as the capital and center of government and business administration, making that form the focus needs to be there many people from the neighboring countries and beyond.

Movement of people in Tirana is very high, every day; there are about more than 170 thousand trips by private vehicles and public transport round destination / Tirana trip. The number of public transport vehicles is only about $2 \%$ of total assets in Tirana.

They were made in the past as well as in Albania in EU countries more research studying why people prefer the use of private cars compared to public transport. And one of the key reasons is that they are not satisfied with the quality of public transport service (Yudiatna 2010,11). The problem in my opinion is in fact the operators have poor management, then do not have the right strategies in business direction for the organization and provision of quality customer service. There is lack of thinking of outsourcing services for customer perfect. They do not have enough responsibility to provide guarantees excellent customer service, this is also whispers that nowadays people in Tirana and beyond are becoming more critical for public transport services. The service is an important issue for passengers. They want to have the best services of public transport; otherwise they will continue to use private vehicles instead of public transport to do their daily activities. If this continues to happen, public transport in Albania will continue to be gripped in the challenge even greater thus making the Directorate of Road Transport Services in Albania in the future even more not efficient and the services that they are useless to citizens.

According to research undertaken by DShTRrSh if there will be significant changes in the development and construction of roads in Albania, as well as developing practical service quality within the departments of its then will face congestion Total traffic ( permanent blocking) in 2019, that unless the government must take serious steps to improve public transport. Building roads in Tirana in particular and in other cities, now growing at a rate of about 0.01 percent per year, and as such is unable to handle the number of vehicles in the capital. Vehicles grow by an average of 11 percent per year.

There are many ways to solve these problems. The most important step is to put the logic of service quality in management policies, which means using "logic dominated by good service" (SD logic) rather than "Common dominance of goodness" (GD logic), as basic thinking to solve the problem. One of thinking to solve the problem is by using performance measurement of Logical dominant service (S-D logic), as a basis for measuring and evaluating public transport.

These measurements can be performed through a balanced evaluation Matrix (BSC). Measuring performance is very important to help in assessing the suitability and performance of the current service. The basic question is: How do we know if the service is good and necessary reforms? The result of the measurement may be used by some actors who need that data. Measuring performance also provides instructions on how to use limited resources effectively and efficiently in the design and operation of government services and policies that reflect community needs. Derived from government policies should be thinking based S-D logic. The logic of public transport actors (especially for policy makers) should be 
changed from G-D S-D logic to logic. GD logic is a sight to do something (transporting someone from a starting point to a destination and providing only the capacity of transport) to process logic SD, which means helping users of public transport to create their process value creation (Enquist et al, 2009). Actors of public transport (especially for policy makers) have to change the logic or thought by thinking of value as something produced and sold to thinking of value as something that is jointly created with customers and other partners (Enquist et al, 2009).

Matrix Balanced Scoreboard (BSC), created by the author Kaplan and Norton. This matrix is a management system that enables organizations to clarify their vision and strategy and translate them into concrete actions (1992).

This model provides feedback on internal business processes and external outcomes simultaneously around them. (1993).

BSC suggests that organizations should be judged from four perspectives, develop quality measuring instruments, collect data and analyze them according to each of the prospects. These prospects are consumers, finance, process and innovation \& learning.

\section{References}

Agency, C. C. (2011). Istraživanjë Tržišta Distributivnë Trgovmë Mješovitom Robom, Pretežno Hranom, Pićima I Proizvodima Za Domaćinstvo U Republici Hrvatskoj U 2010. Godini.

Albaum, G., 1997. "the Likert Scale Revisited: An Altemate Version (Product Preference Testing)" [Online]. Joumal of the Market Research Society, 39 (2), 331. Available from: [Http://Business. Nmsu.

Edu/ Mhyman/M610_Articles/Albaum_JMRS_1997. Pdf]

Baltagi, H. B. (1981), „Simultaneous Equations with Error Components",

Benacek, V., Zemplinerova, a. (1997), Foreign Direct Investillent in the Czech Republic: Environment, Structure and Efficiency in the Manufacturing Sector. Working Papër No. 110, Prague: CERGE-El.

Blanchard, O. (1997), the Economics of Post-Communist Transition,

Carlin, W., Van Reenen, J., Wolfe, T. (1995), Enterprise Restructuring in Early Transition: the Case Study Evidence, Economics of Transition 3(4), 427-458.

Comission, E. (2014). Progress Raport for Kosovo. EU: European Commission.

Communist Economies, Volume 11, No. 1, Pp. 99-125.

Consequences', Joumal of Political Economy, Volume 93, No. 6, Pp. 1155-1177.

Corporatë Përformance: Some Lessons from Transition Economies, Economic Research

Demsetz, H. (1983), 'The Structure of Ownership and the Theory of the Firm', Joumal

Demsetz, H. and Lehn, K. (1985), 'The Structure of Corporatë Ownership: Causes and Development.

Demsetz, H. and Villalonga, B. (2001), 'Ownership Structure and Corporatë

Djankov, S. (1999), Ownership Structure and Enterprise Restructuring in Six Newly Independent Statës, the World Bank, Policy Research Working Papër, No. 2047 (February).

Djankov, S. and Claessens, S. (1997), Enterprise Përformance and Managers" Profile,

Djankov, S. and Murrell, P. (2000), the Determinants of Enterprise Restructuring in Transition: An

DEWATRIPONT, M., L JEWITT, and J. TIrole (1999a): "the Economics of Career Concems, Part I: Comparing Information Structures," Reuiew of Economic Studi. Es, 66, 183-198. - (1999b): "the Economics of Career Concems, Part II: Application to Missions and Accountability of Govemment Agencies," Reoiew of Economic Sullii. Es, 66, 199-217.

FRANKS, J., C MAYER, and L RENNEBOOG (1996): "the Role of Large Share Stakes in Poorly Përforming Companies," Mimeo, London Business School. 
GORTON, G., and G. PENNACCH! (1990): "Financial Intermediaries and Liquidlty Creatlon," Jou11w. L of Finance, 45, 49-71. - (1993): "Security Baskets and Indexed-Linked Securities," Joumal of Bus;11ess, 66, 1-27.

GREEN, J., and J. J LAFFONT (1992): "Renegotlation and the Form of Efficient Contracts," Amuiles D' Econom;E Et De Statistique, 25/26, 123-150. (1994): "Non Verifiabllity, Costly Renegotiation and Efficlency," Anna/Es d'Economie Et De Statistil]Ue, 36, 81-95.

HANSMANN, H. (1996): the Ownership of Enterprise. Cambridge, MA: Belknap Harvard.

HART, 0. (1995a): Firms, Comracts, and Financial Stillct,,Re. Oxford: Oxford Unlversicy Press. -- (1995b): "Corporatë Govemance: Some Theo1y and Implications," Economic Joumal, 105, 678-689.

HIRSCHILLAN, a (1970): £X. ;1, Voice, and Loyalty. Cambridge: Harvard University Press. HOLMSTROM, B. (1979): "Moral Hazard and Observability," Bell Jownal of Economics, IO, 74-91. - (1999): "Managerial Incentive Problems: a Dynamic Përspective," Review of Economic Studies, 66, 169-182.

JENSEN, M. (1986): "Agency Costs of Free Cash Flow, Corporatë Finance and Takeovers," American Economic Review, $76,323-329$.

JENSEN, M., and W. MECKLING (1976): "Theory of the Firm: Managerial Behavior, Agency Costs, and Capital Structure," Joumal of Financial Economics, 3, 305-360.

JENSEN, M., and K. MURPHY (1990): "Përformance Pay and Top Management [Ncentives," Joumal of Political \&Onomy, 98, 225-264.

KAPLAN, R, and D. NORTON (1996): the Balanced Scoreca1d. Cambridge, MA: Harvard Business School Press.

KREMER, M. (1998): "Worker Coopëratives as Economic Democracies," Mimeo, MIT.

KYLE, a (1985): "Continuous Auctions and Insider Trading," Econometrica, 53, 1315-1335.

LA PORTA, R, F. Lopez DE SILANES, a. SHLE!FER, and R VISHNY (1997): "Legal Determinants of

Extemal Finance," Joumal of Finance, 52, 1131-1180.

-( 1998): "Law and Finance," Jownal of Political Economy, 106, 1113-1155.

-(1999): "Corporatë Ownership Around the World," Jounwl of Fill11. Nce, 54, 471-517.

MASKIN, E., and J. MOORE (1999): "[Mplementation and Renegotiation," Review of Economic Studies, 66, 39-56.

MASKJN, E., and J. T!ROLE (1999a): "Unforeseen Contingencies and Incomplete Contracts," Review of Eco11omi. C Studies, 66, 83-114.

--(1999b): "Two Remarks on Propërty Rights," Rel)I. Ew of Eco11omic Studies, 66, 139-150.

NOLDEKE, G., and K. SCHILLIDT (1998): "Sequential Investillents and Options to Own," Rand Joumal of Economics, 29, 633-653.

PORTER, M. (1992): "Capital Disadvantages: America's Failing Capital Investillent System," Hamard Bus;11ess Review, $70,65-82$.

REY, P., and J. TIROLE (1999): "Divergence of Objectives and the Govemance of Joint Ventures," Mimeo, IDE!.

Ros, M. (1994): Strong Ma11age,. S, Weak Ow11ers: the Political Roots of American Corporatë Finance. Princeton: Princeton University Press.

SCHILLIDT, R (1997): "Corporatë Govemance: the Role of Other Constituencies," in Corpora/E Govenumce: Les Përspectives Lmema1io11ales, Ed. by Alia Pezard and J. M. Thiveaud. Montchrestien: Association d'Economie Financiere.

SEGAL, L (1995): "Essays on Commitillent, Renegotiation, and Incompleteness of Contracts," Ph. D. Thesis, Harvard University. --(1999): "Complexity and Renegotiation: a Foundation for Inoomplete Contracts," Rel)I. Ew of Economic Studies, 66, 57-82.

SEGAL, L, and M. WH!NSTON (1998): "the Mirrlees Approach to Mechanism Design with Renegoti- Ation (with Applications to Hold-up and Rlsk Sharing)," Mimeo, Stanford University. 
SHLE!FER, a, and L. SUMMERS (1988): "Breach of Trust in Hostile Takeovers," in Corporatë Takeovers: Causes and Consequences, Ed. by a Auerbach. Chicago: University of Chicago Press, 33-56.

SHLEIFER, a, and R. V1shny (1997): "a Survey of Corporatë Govemance," Joumal of Fi11a11ce, 52, 737-783.

S!NCLAIR-Desgagne, B. (1999): "How to Restore Higher-Powered Incentives in Multi-Task Agencies," Joumal of Law, Ec0110mics, and Organization, 15, 418-433.

SMITH, a (1776): An Inquiry into the Nature and Causes of the Wea/Th of Nati. Ans. New York: Modem Library, 1937.

STEWARD, B. (1994): "'EVA': Fact and Fantasy," Joumal of Applied Corporatë Finance, 7, 71-84. Subrahillanyam, a. (1991): "a Theo1y of Trading Ln Stock Index Futures," Review of Financial Studies, 4, 17-51.

T!ROLE, J. (1999): "Incomplete Contracts: Where Do We Stand?" Econometrica, 67, 741-781. TUR NBULL, S. (1997):

"Stakeholder Coopëration," Jownal of Co-Opëratwe Studies, 29.

V!ENOT REPO RT (1995): "Le Conseil d'Administration Des Societes Cotees," in Rappon Du Camile Sur Le

Gouvememem D' Emreprise Preside Par M. Marc Vie1101. Paris: MEDEF; Http://Www. Medef. Fr / Fr /L/ Lnav/ Lframe. Htill.

WILLIAMSON, 0. (1985): the Eco11omic Jnst;Tutions of Cap;Ta/lsm. New York: Free Press.

ZINOALES, L. (1998): "Corporatë Govemance," in the New Pa/Grave Dictionary of Economics and the Law. London: Macmillan, 497-502. 